\title{
Diseurso do Diretor Geral por ocasião da formatura do Bacharelado em Teologia da FACASC
}

\section{Edinei da Rosa Cândido*}

Senhoras e senhores, bom dia. A Faculdade Católica de Santa Catarina - FACASC sente-se honrada e orgulhosa em poder reunir este seleto público para a realização desta cerimônia de colação de grau, quinta de sua modesta caminhada como Instituição de Ensino Superior.

Um abraço fraterno ao paraninfo, ao patrono, e aos amigos deste grupo de formandos: Pes. Tarcísio Pedro Vieira, Vitor Galdino Feller e Domingos Volnei Nandi respectivamente presentes à mesa junto às nossas autoridades acadêmicas, a quem também saúde: Profs. Patrícia Schmitt Hanh de Lima, digníssima Diretora Acadêmica, Pe. Hércules Marçal, Diretor Administrativo e Pe. Rafael Alex de Lima, Coordenador do Bacharelado em Teologia. Uma deferência aos ilustres membros do CONSUPE - Conselho Superior desta faculdade, presentes nesta sessão solene extraordinária. Considerações de apreço aos demais colegas professores e presbíteros, dentre os quais destaco reitores dos seminários maiores localizados em torno desta faculdade de Teologia; demais pessoas presentes já devidamente mencionadas neste cerimonial. Aparte desses, saudamos o alunado em geral e nossos colaboradores nas mais diversas funções técnica e administrativa desta casa. Menção de destaque aos queridos formandos e seus ilustres convidados, pais, parentes e amigos.

As circunstâncias extraordinárias em que ocorre esta cerimônia levam-nos a apontar para algumas direções esboçando linhas nunca dantes traçadas em ocasiões como esta. E algumas das palavras aqui proferidas, além de homenagem, querem ser de ânimo e encorajamento a esta turma, em certo sentido, marcada por algumas contrariedades e até provações.

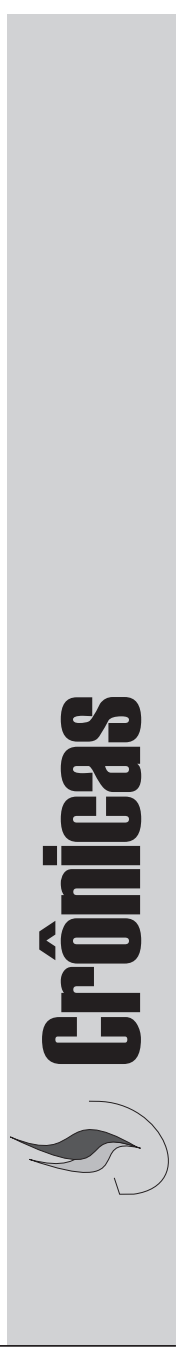


A data de hoje, em nosso calendário acadêmico, é resultado de uma das tantas observâncias normativas que, nem sempre nos dão a prerrogativa da escolha. Uma realidade que embaralhou bastante a jogada final desta grande partida, envolvendo os principais atores: esta Turma de Teologia Pe. Valter Maurício Goedert, nosso decano no colégio docente desta faculdade. Um conjunto de peculiaridades involuntárias, deu a este processo de finalização característica toda própria. Diante da irrevogabilidade de alguns fatos, restou-nos a todos somente resfolegar e firmar propósito para conduzi-lo até este momento, aliviando deste dia possíveis ônus tentando extrair-lhes os melhores bônus.

Excetuando os 34 graduados da convalidação, um processo diferenciado, esta é a maior turma de formandos desde 2015, quando aconteceu a primeira colação de grau da FACASC. Tivemos, assim, até hoje: 2015: 14 alunos; 2016: 15 alunos; 2017: 13 alunos; 2018: 34 aprovados; 25 em cerimônia colaram grau (convalidação); 2018: 16 alunos hoje. O total perfaz 58 e, agora sim somados aos da convalidação, atinge a cifra de 92 .

Um destaque curioso dentre todas essas cifras é que esta cerimônia consegue turmas de alunos do nosso Bacharelado em Teologia de todas as fases, totalizando cinco turmas! Uma iniciante, uma concluinte e duas intermediárias e uma já vislumbrando o fim da estrada acadêmica, a da sétima fase, quarto de Teologia com 21 alunos regulares matriculados.

Esta singularidade é apenas um motivo, entre tantos, de expressão de nosso contentamento, pelo dever cumprido, na parte do conjunto desta manhã, dignificado pelo ato solene da celebração eucarística, presidida pelo nosso professor Pe. Vilmar Adelino Vicente, abrindo esta jornada memorável de ação de graças e festejos, em pleno desenrolar.

Ainda nas estatísticas, em oito anos de atividades a FACASC oferece, majoritariamente para o Estado catarinense, quase uma centena de teólogos, filtrada pelo crivo de seus valores, avaliados e aprovados por seus professores, preparados para testemunharem a sua missão, como instituição de caráter confessional aberta ao ecumenismo e diálogo religioso.

Essa realidade só reforça o propósito de bem formar jovens nesta casa. Fala-se muito em justiça, moral, ética coerência e até em santidade. Entretanto, a prática de tudo isso, em nosso meio e em nossos ambientes, é um apelo que não pode ser esquecido e com o qual não se pode barganhar, diante do exigente processo que comporta o curso de 
Teologia, envolvendo tantos atores, tanto investimento e cercado de tanta expectativa. Externamos aqui, em certo sentido, o lamento pelo fato de que nem todos tenham podido viver este dia. Isso acontece por causa da consciência e busca de coerência nesse longo e melindroso processo. Negligência nesta e outras áreas não têm colaborado para os bons índices na educação e formação superior em nosso país; tampouco tem colaborado para o bom nome e credibilidade da instituição eclesiástica católica pelo mundo afora. (Palavras poucas e veladas para permanecer na amenidade de uma reflexão que poderia ser pesada e demais imprópria para este momento).

\section{[Jovens]}

Resta agora somente manifestar a grande alegria de ter podido colar grau de mais uma turma, na sua maioria de jovens. Somados ao alunado em geral aqui presente formam contingente juvenil expressivo, oportunidade para acenar à expectativa de toda a eclesialidade acerca do Sinodo dos Bispos versando sobre os jovens no mundo de hoje e fé, discernimento, vocação. Com toda a Igreja, queremos caminhar e nos comprometer com a juventude na sua experiência de fé e que, muitas vezes, felizmente, desemboca no caminho vocacional da vida consagrada, carisma venal desta casa há mais de 40 anos dedicada à formação teológica de jovens destinados em sua maioria ao ministério presbiteral.

Assim comunicam os Padres Sinodais em sua Carta aos Jovens do mundo inteiro:

Jovens, "sabemos de suas buscas interiores, das alegrias e das esperanças, das dores e angústias que fazem parte de sua inquietude. Agora, queremos que vocês escutem uma palavra nossa: desejamos ser colaboradores de sua alegria para que suas expectativas se transformem em ideais. Temos certeza de que com sua vontade de viver, vocês estão prontos a se empenhar para que seus sonhos tomem forma em sua existência e na história humana" [...]A Igreja e o mundo precisam urgentemente de seu entusiasmo. Sejam companheiros de estrada dos mais frágeis, dos pobres, dos feridos pela vida. Vocês são o presente, sejam o futuro mais luminoso."

A esta citação poderíamos acrescentar tantas outras expressando o carinho e a proposta da Igreja e do Papa para os jovens. Quanta irradiação nos trouxe a Jornada Mundial da Juventude, realizada há poucas semanas 
no Panamá, difundindo no mundo inteiro a alegria juvenil visível em milhares de rostos, dentre os quais se percebe tantos com a tez marcadamente indígena da juventude latino-americana, que os mais de 500 anos de conquista (e até genocídio) não conseguiram apagar. É preciso viver o presente com todo o vigor e encantamento juvenis sem adiar para o futuro o ser e estar no mundo. $\mathrm{O}$ aqui e agora exige compromisso e engajamento. E é olhando o presente que a FACASC alegra-se em poder fazer parte da história de uma centena de teólogos, seus ex-alunos, que ajudarão o tempo presente a viver suas experiências, solucionar seus problemas e curtir seus dramas.

\section{[Papa Francisco]}

Tanta lama, tanto lodo e tanta expectativa política quase que não permitiram notar o grande acontecimento no início deste novo ano: a Visita do Papa Francisco aos Emirados Árabes. Há muito tempo atrás, no culminar da Idade Média, vencendo todas as barreiras que dividiam cristãos e muçulmanos numa sangrenta e paradoxal "guerra santa", um homem muito pobre e simples consegue furar o bloqueio e as linhas do campo de batalha, no coração do Oriente, e vai ter com o sultão em meio à sua corte. Francisco de Assis encontra-se com Melek El Kamel. Anuncia-lhe o Querigma e desafia-o à prova de fogo (real!). Isso deu-se em 1219, no declinar do reinado de Inocêncio III, no auge do poder temporal do papado. Indiscutivelmente, uma grande façanha.

$\mathrm{O}$ fato único ficou registrado, em detalhes, nos escritos de um dos biógrafos mais fidedignos do santo: São Boaventura, o Doutor Seráfico, na sua Legenda Maior $(9,8)$. Passados exatos 800 anos, o prodígio se repete. De um lado, o presidente dos emirados, o Califa bin Zayed al Nahyan e um séquito de moasins imans, mulás e mustafás; do outro lado, um homem muito simples e pobre, um chefe de Estado sem aparato, um pontífice sem série, sem número, original, simplesmente Francisco, Servo dos servos de Deus.

Os Emirados Árabes Unidos nunca estiveram tão unidos. Protocolos e salamalecs à parte, com assombro e entusiasmo o mundo testemunhou estarrecido: a cruz, apoiada ao peito do ancião, adeja leve pelos arabescos dos palácios do califa; a cruz, despretensiosa, coloca-se ante a meia lua e ambas, coisa maravilhosa, enlaçam-se e celebram o anseio de todos os homens de boa vontade: a fraternidade universal. 
À despedida, sob tolerância, silêncio, respeito, dos muçulmanos, e muita fé dos católicos que lá vivem, a hóstia é ofertada, consagrada e, pode-se ver o que muitos ansiaram por ver: erguida, a hóstia e sobressai às tendas do harein e eleva-se no coração do Islã! Homens da pós-modernidade que somos, do conforto de nossas poltronas, assistimos mas não vemos e, se vemos, incrédulos, não cremos!

São Francisco e o sultão Melek El Kamel em Damieta: 1219; Papa Francisco e Califa bin Zayed al Nahyan, capital dos Emirados Árabes: 2019. Passaram-se 800 anos!

Conta-se que, ao chegar ao céu, São Francisco ocupou, junto de Deus, um trono luminoso, aquele deixado por Lúcifer. Embora se trate de uma tradição medieval, muito piedosa, é oportuno o interrogativo: Quem é o príncipe deste mundo? Quem são os príncipes deste mundo?

O belo e extremamente proveitoso é tomar contato com (mais do que isso: sentir-se movido) alguns dos trechos dos discursos lá proferidos e apreciar o desarmamento irrestrito: braços desarmamos, desarmamento real, mente e coração desarmado, desarmamento total; e perceber os frutos do progresso e dos benefícios e um são, comprometido e ousado diálogo religioso no que tem sido definido nessa visita como polifonia da fé.

Estes são alguns dos caminhos por onde nos levam a humildade, despretensão e profundo espírito evangélico. Teólogos, levem esse espírito em sua bagagem. Boas oportunidades vocês tiveram de cultivá-lo em nossos espaços durante quatro anos. Não almejem tanto, mas realizem um mínimo. Perguntem-se e respondam-se que espaço e lugar ocupam a dimensão ecumênica e dialógica na sua confessionalidade pessoal.

\section{[Missões]}

Nosso coração deve ser apostólico e universal, somos católicos! Ele leva-nos a contemplar muitos horizontes e novas dimensões: janeiro e fevereiro deste ano de 2019: alunos da FACASC em missões na Guiné Bissau, fazendo vibrar o coração missionário da nossa Igreja local. É algo inusitado nos quase 50 anos do nosso Regional Sul IV e do próprio ITESC/FACASC. Aos poucos entre nós, o COMISE - Conselho Missionário Seminarístico vai tomando forma.

Em março estaremos comemorando os 470 anos da chegada da Companhia de Jesus no Brasil. Nas pegadas e no testemunho de 
São José de Anchieta e outros, muitos jovens jesuítas, desde 1549, vieram para o Brasil e nunca mais voltaram. Ele é o missionário, o visionário, o homem de Deus, que foi capaz de semear. Nem ele nem aqueles outros homens, na metade do século XVI, em meio à cristandade dilacerada na Europa, não sabiam que, no Brasil, estavam lançando as bases da maior nação católica e cristã do planeta, vastíssimo campo missionário. Mesmo assim, com fé e coragem, simplesmente semearam regaram com o próprio suor, lágrima, e até sangue, esta bendita Terra de Santa Cruz!

Também o nosso espaço nacional mereceu o zelo apostólico de nossos estudantes e a Ilha de Santa Catarina cedeu lugar à Ilha de Marajó. Que o ardor missionário entre nós não seja somente marcado por decretos e comemorações extraordinários e que sejam esconjuradas, por completo, a tentação da busca de mais uma rota de entretenimento e fuga para as férias, ainda que com um sabor de aventura, uma pitada de risco e um refolho de piedade. Por isso é oportuno perguntar: Os que foram tem disposição para voltar; se voltarem terão perseverança para permanecer? Por quanto tempo? E nós outros, que sequer ainda fomos, teremos um dia disposição, decisão e tempo para partir?!

\section{[Palavras finais]}

Queridos formados, a vocês congratulações, pedido de culpas abraço fraterno e muito carinho. Entristecemo-nos em deixá-los partir. Todavia, num certo sentido, vocês já são o passado porque estão nos deixando hoje para viver o presente como teólogos e, como teólogos, semear o futuro. Doravante Vocês seguirão novos caminhos e a FACASC continuará sua nobre missão de iniciar, sobretudo jovens, nas sendas da Sagrada Teologia.

\section{[Novo PPC]}

Com essa renovada disposição de continuar a cultivar e semear, convidamos os alunos da primeira fase, presentes, a se levantarem. Vocês estão iniciando o Curso de Teologia e são a nossa maior promessa de presente em vista do futuro. Bem-vindos em nosso meio. Declaro-lhes, abertamente, que estamos iniciando com vocês, esta semana, um novo perfil do nosso curso, um novo Projeto Pedagógico (PPC). 
A FACASC se dispõe a, seguindo as normativas vigentes, e adequando-se a novas situações, efetivar esse novo PPC (Projeto Pedagógico do Curso) com uma nova grade curricular, a terceira em sua curta história de uma meia dúzia de anos. No mais, a nova Ratio Fundamentalis Institutionis Sacerdotalis da Congregação do Clero (08.12.2016) constituiu material precioso a ser levado em conta na elaboração desse novo projeto formativo, com a proposta configuradora, posto que nosso Bacharelado em Teologia tem reconhecimento também no âmbito eclesiástico conferindo aos alunos o grau de bacharel mediante o exame $D e$ Universa. O nosso ITESC Instituto Teológico de Santa Catarina, em plena atividade, mantém convênio, firmado para este fim, com o CES (Centro de Estudos Superiores) da Companhia de Jesus em Belo Horizonte. Portanto, também bebemos nessa fonte comum da Igreja na orientação da Sagrada Teologia com vistas à formação presbiteral.

Nesse contexto é importante informar que o perfil do acadêmico da FACASC foi cuidadosamente refletido, discutido, experimentado e, finalmente, regulamentado. Espera-se, com isso, que as aventuras rocambolescas de alunos, grades e disciplinas, se não cessadas, ao menos caiam vertiginosamente, dando maior objetividade e seriedade àqueles que se dispõem a sentar em nossos bancos, sejam como aluno regular, especial, ouvinte, seguindo a nova nomenclatura. Que cada um chegue com a convicção de quem sabe para que veio, permaneça firme no seu propósito e prepare, com seriedade, sua conclusão evitando todo tipo de atropelo.

Por último, convido vocês todos a se alegrem comigo, pois em $1^{\circ}$. de janeiro iniciei último ano de minha direção geral e celebro 25 anos de magistério aqui na FACASC/ITESC, acelerando e estreitando os passos para celebrar já, neste mesmo ano, 25 anos de ministério ordenado, recordo o lema de meu diaconato e deixo-lhes como reflexão: "Tudo vale a pena se a alma não é pequena".

Muito obrigado a todos; aplausos aos que vão, vem e por aqui passam!

Florianópolis, 21 de fevereiro de 2019

Pe. Dr. Edinei da Rosa Cândido

Diretor Geral da FACASC 